\title{
ポリフェニレンェーテルのランダム開裂を仮定した 数值計算による熱分解過程の研究
}

\author{
近藤 博昭*1・木下 雅夫*1・土屋 敏明*2・武田 邦彦*1
}

（受付 1996 年 8 月 1 日・審査終了 1997 年 2 月 7 日）

\begin{abstract}
要 旨 コンピューター・シミュレーション手法を用いてポリフェニレンェーテル (PPE) の分解生成物の組成 を求め, その結果に基づいてPPE の熱分解過程の研究を行った。 その結果ベンゼン環が一つからなる単環体およ び二つの二環体のいずれにおいてあコンピューター・シミュレーションの結果と実験値は良好な一致を見た. 特に 単瓄体の実験結果より推定した転位反応と開裂反応の確率パラメーターを用いた二環体のシミュレーション結果 は実秧値をよく説明する．また本熱分解条件におけるPPE 主鎖のエーテル結合からメチレンフリッシシへの転位率 は78\%であった，さらに側銷メチル基の切断確率は主鎖の切断確率よりかなり小さく，2〜4\%と求められた，複 雑な高分子の熱分解過程において, 実験から多くの反応の閚裂確率を定量的に求めることは困難であり, コン ピューター・シミュレーションを用いることが有用である. さらに本研究の結果, PPE の熱分解過程に関する反応 経路がさらに明らかになったとともに，ランタム開裂を仮定した高分子の熱分解の数值計算方法が有効であること を示した。
\end{abstract}

\section{1 腥言}

近年計算機の急速な進歩により，高分子のさまざまな 研究分野に計算機が用いられるようになり, 学会誌であ 計算機を用いた研究の特集を組むに至っている゙。. 高分 子材料の数值計算の多くは金属材料, 無機材料の分野の 計算と同じく, 量子化学的手法, 分子動力学, モンテカ ルロ法, またさらに実用的な面では有限要素法, 数值流 体計算などを応用したものである2).31.これらの数値計 算は高分子材料の合成，構造設計，物性解析，および成 形分野で欠くことのできないあのであり, 高分子化学の 発展に貢献をしている4). 5).

本論文での数値計算はこれらの現在発展しつつある高 分子分野の数値計算方法とはその目的と手法および考え 方を異にするすのである．高分子の合成や構造，特性の 研究を進めていくとき, 研究者はしばしばたいへん複雑 な実験デー夕に遭遇する，その複雑さは主に低分子から なる有機合成化学や反応化学よりも複雑であることが多 い，それは高分子が巨大な分子を取り扱い，またポリ マーアロイなどのさらに複雑な系を取り扱うことに起因 している.このような場合研究者はそのデー夕解析を簡 単な数学を用いて計算することはできず，時として先人 の研究した解析式を用いてもその一部しか解析できない

*1 芝浦工業大学材料工学科（-108 東京都港区芝浦 3-9-14）

*2 芝浦工業大学地球環境システム専攻（⿶108 東京都港区芝 浦 3-9-14)
ことが多い．あっとあ高分子の熱分解を初めとした現象 は複雑でいかに優れた微分方程式をもってしても多くの 仮定のあとで式を立てなければならない6). また熱分解 の場合のように有用な数式が研究されていてあ，熱重量 分析における分解速度と分解生成物の沸点の関係すらも 支配因子として入力できないのが現状である7”.

このように多くの実験の場合に解析式が使えない高分 子研究の分野に，急速な発達を遂げている数值計算を用 いることはたいへん役立つ.しかし分子動力学などの極 度に専門知識を要求されるものや, 有限要素法その他の 計算手法のようにすでに完成され，市販されているンフ 卜を応用できる範囲に限定される数值計算は高分子研究 の一部にしか有効ではない，本論文ではエンジニアリン グプラスチック，特にその中でポリフェニレンェーテル (PPE) の熱分解反応を取り上げ，高分子研究のための 新しい数値計算方法を提案するとともに数值計算によっ て新たに判明したPPE の熱分解過程についての研究結 果を報告する。

\section{2. 計算のスキームと計算手法}

PPE に熱を加えるとPPE の温度が上昇し，分解反応 と転位反応が起こる可能性が示されている8),99.さらに 最近の研究によってPPE の熱分解の時の転位反応はx チレンブリッジ反応と呼べるもので, その反応スキーム は Fig. 1 に示されることが明らかになりつつある ${ }^{10)}$.

メチレンブリッジ転位反応はPPE 類似の低分子化合 物について Factor が実験しており，370 $\mathrm{C} ， 5 \mathrm{~min}$ 程度 
で反応が進んでいる"1. また木下らの実験によれば高分 子量の PPE の場合でもメチレンブリッジ反応は $400^{\circ} \mathrm{C}$ 近傍である可能性が指摘されている ${ }^{12}$. ししたがって, 転 位反応の前後の構造を含んだ熱分解過程のうち, ベンゼ ン環が 1 個からなる分解生成物（単環体と呼称する）が 生成する主たる「主鎖の開裂箇所」は Fig. 2 に示す.

ここで, (a), (b), (C), (1) は開裂䇢所を示す.

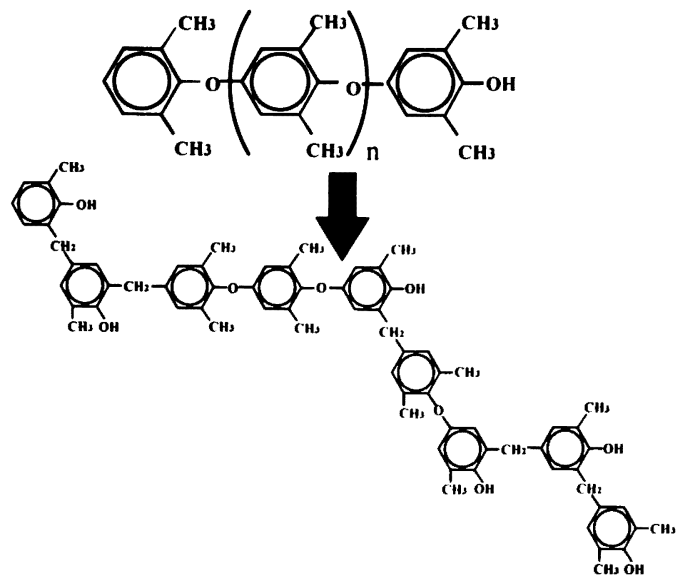

Fig. 1. Chemical structures of PPE before and after rearrangement reaction.
以上の知見から本計算では次のような計算モデルを立 てた.

(1) 1 本の高分子鎖は，実験で使用したPPE の重合 度から 510 とした。

(2) 主鎖の転位反応については，PPEの主鎖がメチ レンブリッジ転位を起こし，また起こしつつ主鎖や側銷 の開裂が進むこと．転位反応は PPE 主鎖の特定の部位 で選択的に反応が進むのではなく、ランタムに転位が起 こるものとした，具体的には転位反応の場所は FOR-
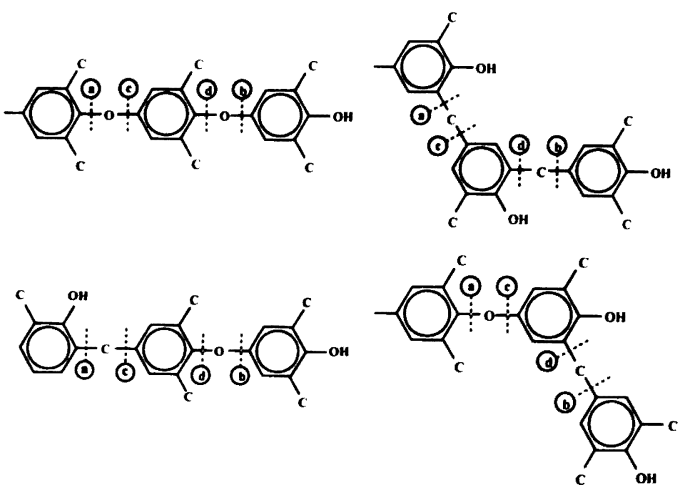

Fig. 2. Cleavage points to produce monomeric scission products. (a), (b), (C), and (d): cleavage points.

Table 1a. Probability of rearrangement

$\begin{gathered}\text { Probability } \\ \text { of reactions }\end{gathered}$ Symbol
$R_{r_{0}}$


ポリフェニレンェーテルのランダム開裂を仮定した数値計算による熱分解過程の研究

Table 1b. Probability of main-chain cleavage and side-chain cleavage

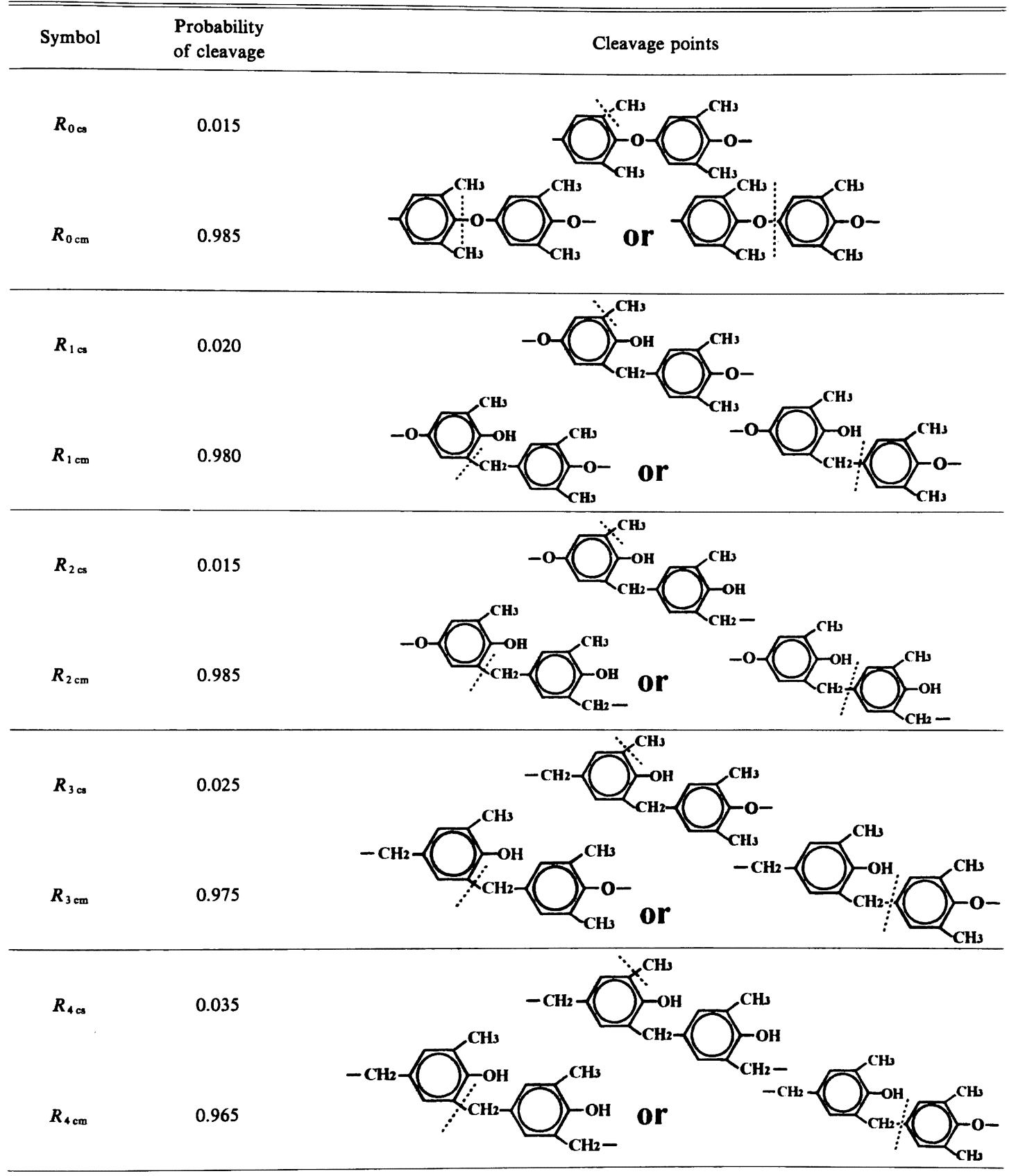

TRAN 上で乱数を発生させ場所を特定した ${ }^{13) \sim 15)}$.

(3) 主鎖の開裂部位は転位前のエーテル結合が開裂す るときす，転位後のメチレンブリッジ転位反応が開裂す る場合であ規則的な開裂や特別な位置の開裂ではなくラ ンダム開裂が進むとした。 ただし，エーテル結合の開
裂, メチレンブリッジ転位反応の開裂は，それぞれにつ いての開裂確率を独立に決定するようにした ${ }^{16)}$.

(4)隣接結合の影響として, 同じェーテル結合やメチ レンブリッジ結合であべンゼン環を隔てて，エーテル結 合が存在するか, またメチレンブリッジ結合であるかに 
Table 1c. Probability of cleavage points on main-chain

Symbol

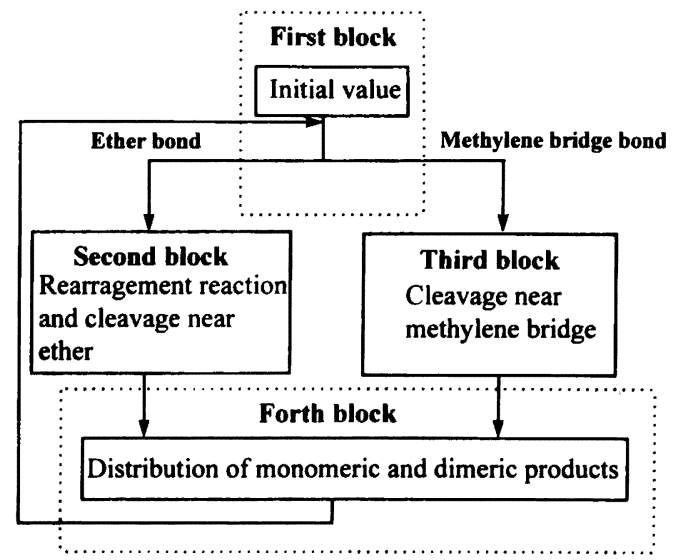

Fig. 3. Block flowsheet of computer simulation for thermal degradation of PPE.

よって開裂速度が異なる可能性がある.そのため, Fig. 2 の構造を基本として前後の結合によって異なる開裂確 率を計算しうるように開裂確率記号を分割した。

(5) 側鎖メチル基の開裂屯主鎖の開裂とともに起こる とし,さらにその開裂の確率は周辺構造について異なる 開裂確率をもつとした。

以上の仮定に基づき，開裂確率値として，(1)切断反応 が起こる瞬間の主鎖構造について 5 種類 (Table 1a), (2) 5 種類の構造を基準とした側鎖の開裂確率值 (Table 1b), および(3) 5 種類の構造に基づく主鎖切断の開裂確 率値 (Table 1c) の3グループに分け, Table 1a, b, お よび cに整理した.

Table 1 には併せて計算結果を示したが, 值について は結果の項で述べる. Fig. 3 に転位, 開裂反応の全体の 数值計算フローチャートを示した.

重合度, 初期の開裂確率などの初期値を設定し, 乱数 を発生させた後，その乱数によって特定された箇所の結 合様式を判断し，それぞれの構造ごとに転位反応，開裂 反応などの同じく乱数を発生させて, ランダムに反応, 開裂をさせる. その後, 1 回の計算ごとに単環体, 二環 体（ベンゼン環を二つ含む分解生成物）を積算し，あら かじめ設定した比率になったところで計算を終了させ た. 実験値之同一の条件の場合には実験的に得られた単 環体と二環体の比率（単環体 74 に対して二環体 26）を 終了条件とし，計算上必要な条件のときには目的に応じ たさまざまな終了条件を設定した.

さらに, 単環体分解生成物の実験結果に対してシミュ レーションして得られた転位反応, 開裂反応の反応確率 を用いて, 熱分解の途中で発生する二環体の生成を計算 した. Fig. 4 に二環体が生成する開裂場所を示した. 収束の方法は反応確率を変更して分解生成物を求め, 


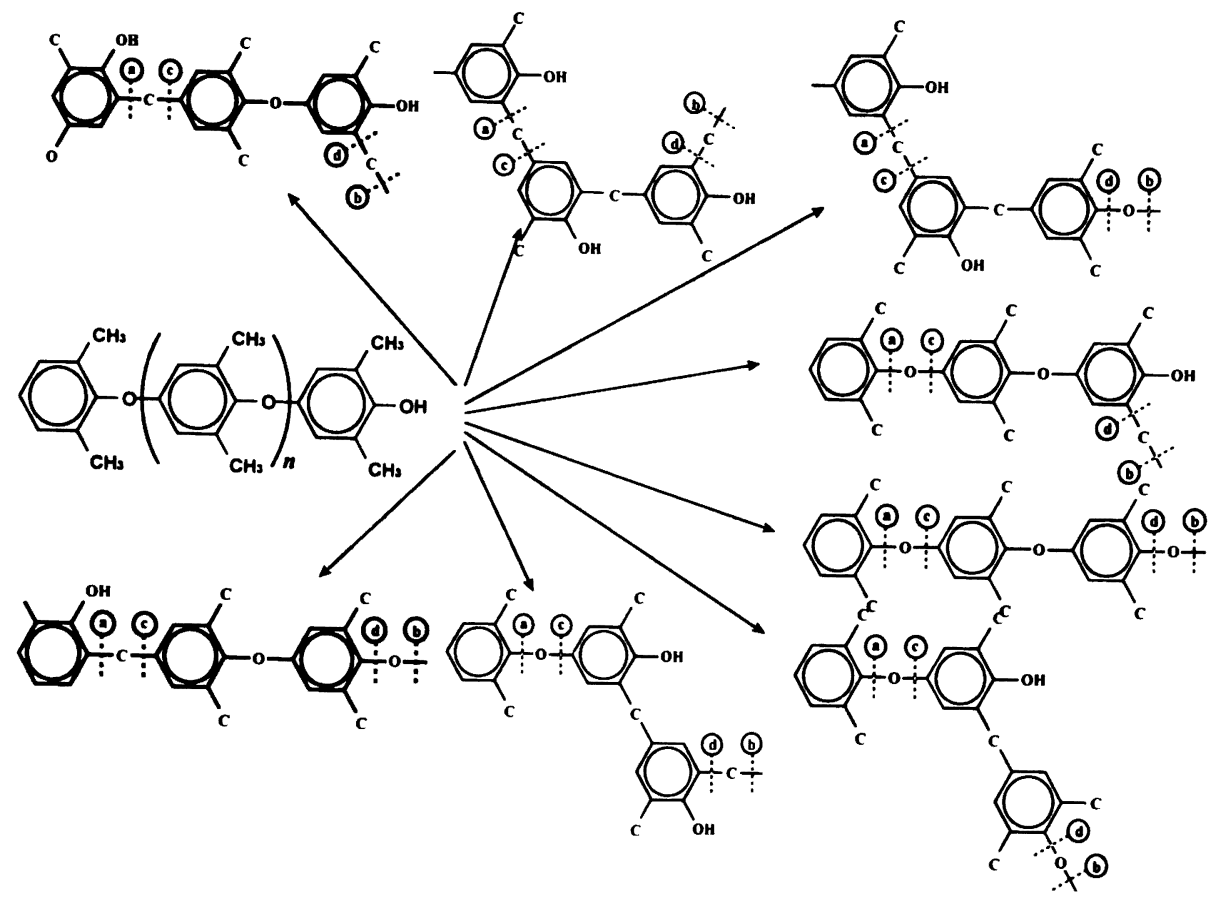

Fig. 4. Cleavage points for producing dimeric scission products. (a), (b), (C), and (d): cleavage points.

計算で求めた分解生成物と実験的に得られた生成物の量 を比較してその差の二乗を取り, 単環体分解生成物全体 にわたる総和を取る方法である。このような差の二乗の 値の最小值を求める収束問題で最も注意を要することの 一つは収束点がーつではなく収束曲面に複数の「くぼ み」をもつ場合が想定される. 収束に関する数学的な式 が得られている場合には収束曲面のくぼみの存在をある 程度予想をすることができるが，本研究のように解析式 を用いない場合には数值計算自体でくぼみの可能性を当 たり, 収束がくぼみに宿いらずに真の収束値になるかを 予備的に検討する必要がある. この検討を代表的な反応 についてその確率の計算について行ったが，ここではそ のうち $\boldsymbol{R}_{2 \mathrm{cmr}}$ および $\boldsymbol{R}_{3 \mathrm{cmr}}$ の反応確率の収束計算の場合 について Fig. 5 に示した.

この一例からは収束曲面はなめらかであり収束が部分 的なくばみに陥いることはないということがわかる。し かし収束計算の例を一つ示しただけでは全体を把握する ことは困難である. 計算過程で予期せざる組成になり， それがくぼみを作ることも考えられるからである．PPE の転位および分解反応においては永続的なくばみは生じ にくいと考えられる.すなわち，ある特定の組成にくぼ みを生じた場合, 仮に真值ではない値に収束することに なるが, 次の反応は別の反応が起こるのでその反応で全 体のPPE の分解の組成が変更される. ある程度の計算

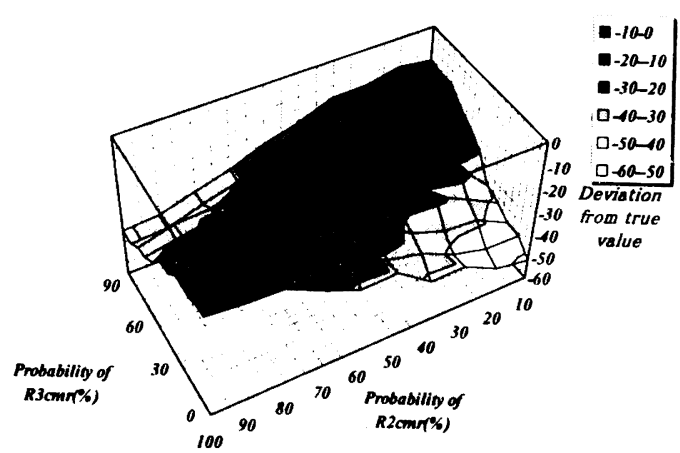

Fig. 5. Two-dimensional conversion curve in the case of $R_{2 \mathrm{cmr}}$ and $R_{3 \mathrm{cmr}}$ reactions.

を経てくばみを生じた反応確率值が収束した場合，前の 計算とは別の場所からの収束計算になるので同じくぼみ に収束する可能性は格段に低いと考えられるからであ る.このように反応確率を決定して, 反応の選択を行い ながら計算する場合にはくぼみへの収束を避けるという 利点もある.

なお, 本研究ではプログラム言語として MSFORTRAN (Power station Version 4.0), CPU は Intel 社 Pentium $133 \mathrm{MHz}$ を使用したが, 数式は使用していな い. 


\section{3 実験方法}

本論文はPPE の熱分解に関する数値計算方法とそれ による新しい熱分解機構に関する知見の報告であるの で, PPE の合成方法, 熱分解実験方法, および熱分解 構造解析, 分析方法については概要を記述するにとどめ る．実験上の詳細は文献を参照されたい(17)，18)，26 DMP はフェノールとメタノールを触媒下で反応させて得られ た粗 26 DMPを精溜して得たものを用いた。重合触媒 として塩化第二銅・ 2 水和物 $\left(\mathrm{CuCl}_{2} \cdot 2 \mathrm{H}_{2} \mathrm{O}\right)$, 触媒助剂 として $N, N^{\prime}$-テトラメチル-1,3-ジアミノプロパン, $N$ - ジnーブチルアミンを用いた。

塩化第二銅・ 2 水和物と $35 \%$ 塩酸, メ夕ノール, ジ $n$-ブチルアミン, $N, N, N^{\prime}, N^{\prime}$-, テトラメチル-1,3-ジアミ ノプロパンをキシレンに溶解し，26 DMP を加え，酸素 を供給しながら $40^{\circ} \mathrm{C}$ で反応を行い, 白色粉末のPPE を得た ${ }^{19}$.

熱分解実験は熱分解装置に日本分析(株)製のキュリー ポイントパイロライザー(JHP-22)をまた Perkin Elmer 社製ガスクロマトグラフィー(GC-17A) を用い た. 分解炉の温度は $510^{\circ} \mathrm{C}$, カラムは $0.25 \mathrm{~mm} \phi, 30 \mathrm{~m}$ のキャピラリーカラム（液相は $5 \%$ フェニルメチルシロ キサン）を用いた。 また示差熱天秤一質量分析計を用い た分解生成物の定性分析測定では，(株)リガク製 TGDTA-MS で室温から $800^{\circ} \mathrm{C}$ まで昇温し $400 \sim 700^{\circ} \mathrm{C}$ の 分解成分をフラクションに分けて採取し, 質量分析し た. 単環体の定性分析は市販の同定ソフトを用いて同定 が可能であったが，二環体の場合は質量分析のチャート と従来の文献値から推定した ${ }^{200}$.

\section{4 結果およひ考察}

PPE の転位反応や主鎖の開裂などの個別の反応につ いてその反応速度の絶対值および相対值を設定するに際 して, 2 通りの方法が考えられる. 一つは反応速度を実 験から求め，その反応速度を用いる方法である。この場 合においては計算の過程で時間軸を小さな時間単位に刻 み, 特定の反応が開始する時間に達したところで反応を 行わせる. また, 別の方法では特定の反応についての反 応確率を定め, まず特定反応を選定して, 乱数発生によ り反応確率より反応を進める方法である.この場合に は, 乱数が反応確率より小さな数を得た場合には反応を 実行し, 大きな数を得た場合には別の反応を選択する方 法である.この二つの方法で得られた計算結果は最終的 に相互に換算が可能であるが, 本研究の様な開裂様式の シミュレーションの場合には反応確率を用いた方が高分 子銷の反応の様子を直接的に数值計算上で据えることが できるので望ましいと考えた.

収束計算を行って最初に求まる結果は単環体の組成で
あり, Table 2 に単環体の生成比率の収束計算値結果お よび実験値を示した。

単環体の主たる分解生成物は 4 種の化合物 (o-cresol, 2,4-dimethylphenol, 2,6-dimethylphenol, および 2,4,6-trimethylphenol) であり, その生成量はほぼ同じ程度の量 であった．その他の化合物は四つの単環体に比較して少 なかった。このような特徽及び個々の単環体の実験値と 収束計算值の組成は良い一致を見た。得られた反応確率 値を Table 1a，b，および c に示した.

反応確率はそれぞれの種別についてその和を 1.0 とし て表記した．この計算で得られた熱分解過程時の主鎖の 転位確率は 1.0 から Table 1a の $R_{r 0}$ を引いた值になるの で, 主鎖の転位確率は 78\% という結果を得た. 熱分解 の実験において主鎖の開裂に先んじてある程度のエーテ ル結合が転位していると推定されたが，それが $80 \%$ 程 度であることが定量的に推定できた。すなわち PPEが 熱によって単純に開裂する場合には 2,6-dimethylphenol が生成するし，さらに側鎖メチル基が脱離する場合には $o$-cresol, phenol が生成する. しかし, 2,6-dimethylphenol, o-cresol とほぼ同量の 2,4-dimethylphenol, 2,4,6́trimethylphenol が生成しているので, メチレンブリッ ジ転位を経て主鎖開裂が進んでいるという推定が定量的 にも可能となった.

また, Table 1a に示した転位後の構造を示す四つの パターンではベンゼン環相互のブリッジが, C-C-C-で あるあの $\left(R_{\mathrm{ra}}\right)$ が，主鎖すへててを基準にすると $43 \%$ ，転 位したすべての構造を 1.0 とすると $55 \%$ と計算され, 転位構造の中では最も多く, その他の構造は約 $15 \%$ 程 度であった。

次に, Table 1bに示したようにこの四つの転位構造 および未転位の構造のいずれについても側鎖のメチル基 脱離の確率は低く，主鎖の開裂確率が 97〜 98\% 程度な

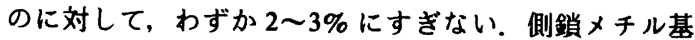
とベンゼン環との結合エネルギーや開裂後の化合物の生 成エネルギーなどからの説明はむずかしいが, 高分子鎖 全体の立体構造からあたらされる結合の歪みが主鎖が優 先的に開裂する原因と考えられる. Table 1c からエーテ ル結合の主鎖の切断は, “4”位での切断が $89 \%$ に対し て, “1”位の切断が $11 \%$ と異なるが,これは2,4,6trimethylphenol の開裂反応と同様の傾向を示していると 考えることができる。また，メチレンブリッジの場合に は,この 1,4位の差はエーテル結合ほど大きくなかっ た.さらにエーテル結合とメチレンブリッジの連鎖の順 序により,メチレンブリッジの開裂確率に顕著な差があ ることが明らかになった。メチレンブリッジに隣接する 結合がエーテルの場合, para 位の開裂は著しく抑制さ れる.これは Table 1c の構造図の左の結合がエーテル の場合には $R_{2 \mathrm{cmr}}$ と $R_{2 \mathrm{cml}}$ が 0.90 と 0.10 であり, その反 
ポリフェニレンエーテルのランダム開裂を仮定した数值計算による熱分解過程の研究

Table 2. Experimental and simulation of monomeric scission

\begin{tabular}{|c|c|c|c|}
\hline Symbol & Structure & $\begin{array}{c}\text { Experiment } \\
(\%)\end{array}$ & $\begin{array}{c}\text { Simulation } \\
(\%)\end{array}$ \\
\hline A1 & & 1.16 & 0.95 \\
\hline B1 & & 19.26 & 22.13 \\
\hline $\mathrm{C} 1$ & & 1.75 & 0.85 \\
\hline D1 & & 28.57 & 27.35 \\
\hline E1 & & 25.24 & 24.17 \\
\hline F1 & & 0.35 & 0.21 \\
\hline G1 & & 22.66 & 22.56 \\
\hline H1 & & 1.01 & 0.75 \\
\hline I1 & & - & 0.32 \\
\hline J1 & & - & 0.23 \\
\hline $\mathbf{K} 1$ & & -- & 0.26 \\
\hline
\end{tabular}

対に右の結合がエーテルの場合に 0.20 と 0.80 と逆の結 果を与えた。後に述べるうにこの結果は実験的に得ら れる二環体の組成から推定される開裂確率を定量的に示 している.

以上のように本計算によって実験で得られた結果を詳 細に解析を行うことができるが，これは本研究の主たる 目的ではない.むしろコンピューター・シミュレーショ ンの目的は実験で得られ，その解釈を行ったものがコン ピューター・シミュレーションの手法加らあ裏付けられ るか否かという問題であるので, むしろ実験からの解析 に依存しないことが必要であると考えられる.

次に本研究で計算の仮定として用いたPPEの分解ス キームが PPE の実際の分解過程と一致し, かつ単環体 の結果に基づいて求めた反応確率が PPE の分解確率と 一致しているならば, Table 1a, b, および c の反応確率 を用いて計算した二環体の分解生成物の結果も同時に実 験値に一致するはずである。この場合には実験で得られ た二環体の分解生成物の組成は反応確率の収束に当たっ て全く参考にしていないのであるから，シミュレーショ ンで強引に反応確率を合わせる方法とは本質的に異な る. すなわち計算をする上で考えているシミュレーショ ンのスキームが不適切な場合には, 単環体の実験值を用 いてシミュレーションした結果を用いて，二環体生成物 の予測をすれば実験値と異なる結果を与えるであろうと 考えられるからである.この計算を行った結果を Table 3 に示した.

実験的に得られた二環体の組成は顕著な傾向が見られ る、メチレンブリッジで連結されたベンゼン環を有する 4 種の二環体 (E2〜H2) は主たる分解生成物であり，そ の回収量は 15〜20\% 程度である. またエーテル結合で ベンゼン環が連結された 4 種の二環体 (A2〜D2)のう ち, 左側の para 位にメチル基を持たない $\mathrm{A} 2$ と $\mathrm{B} 2$ の回 収量が少なく、メチル基を有する C2 と D2 の回収量が 多い，この二環体における実験值はコンピューター・シ ミュレーションの結果は良好に一致している。一見類似 化合物と考えられる I2 L2 が極めて少ない量しか回収 されないことも合致している.

しかし、コンピューター・シミュレーションは対象と なる科学的事実を実験と異なる方法で明らかにするため の手段であり, コンピューター・シミュレーションの結 果が実験結果と一致したという結果自体は意味のあるこ とではない，本研究の場合，単環体の分解生成物の実験 結果を応用してコンピューター・シミュレーションで計 算された転位, 分解反応の確率比を用いて計算した, 二 環体の計算結果が実験で求めた複雑な組成と一致したと いう結果は次の意義があると考える。

1. 数値計算ではPPEが主鎖の分解をする前にメチ レンブリッジ転位をすると考えられる。 
Table 3. Results of simulation for dimeric scission products by using cleavage parameters obtained in monomeric products simulation

\begin{tabular}{|c|c|c|c|}
\hline Symbol & Structure & $\begin{array}{c}\text { Experiment } \\
(\%)\end{array}$ & $\begin{array}{c}\text { Simulation } \\
(\%)\end{array}$ \\
\hline A2 & & 1.19 & 3.77 \\
\hline B2 & & 2.32 & 4.55 \\
\hline $\mathrm{C} 2$ & & 11.15 & 10.53 \\
\hline D2 & & 13.66 & 12.09 \\
\hline E2 & & 17.06 & 17.81 \\
\hline F2 & & 20.59 & 18.98 \\
\hline G2 & & 14.76 & 13.78 \\
\hline $\mathrm{H} 2$ & & 17.32 & 16.76 \\
\hline I2 & & 0.95 & 0.52 \\
\hline J2 & & 0.14 & 0.39 \\
\hline $\mathrm{K} 2$ & & 0.85 & 0.26 \\
\hline L2 & & 0.00 & 0.00 \\
\hline
\end{tabular}

2. メチレンブリッジの開裂は隣接するフェニル基が エーテル結合の場合にはエーテル結合側のメチレンブ リッジの開裂速度が遅いこと, 側鎖メチル基の脱離は主
鎖の開裂より速度が遅いことなどの主要な数値計算上の 過程が実際の開裂状況と一致している可能性が高い.

3. 一次反応確率, ランタム開裂という簢単な仮定と 
高速計算機を利用することにより，従来の解析方法では 明らかにできない定量的な結果を得た。

特に上記の第 3 点は本報告で強調したい点の一つであ る. 実験的にかなり膨大なデータを集積しても，数個の 異なる開裂確率を求めることはもとより，転位確率のよ うな一つの数値を求めることも困難であるからである.

分子動力学, 有限要素法などの既存の計算手法は高分 子の解析に有効であるが, 計算にある程度の専門的知見 が必要であるということも否めない，本研究で用いた数 值計算プログラムは一般的に手に入る FORTRAN プロ グラムを用いており，その計算手法も特別の手法を用い ていない．特に数式を使用せず，「口頭で高分子の分解 過程を述べるように，そのままプログラミングする」と いう，いわば「ロ述プログラミング」が高分子の熱分解 の解析に有効であることを示した．高分子の研究者自ら が解析用のプログラムを作成し, 自らの実験データの解 析をより樑く行うことは極めて有意義なことであると考 えている.

\section{5 哧論}

PPEの熱分解反応を主鎖のメチレンブリッジ転位反 応とランタム反応および開裂を仮定したコンピュー ター・シミュレーションにより解析した. ベンゼン環一 つを含む単環体の組成を実験的に得て, その単環体の構 造と組成からPPEの熱転位反応の構造を仮定した，そ の仮定に基づき，転位部位，開裂部位を仮定し，実験で 得られた単環体の組成が合致するように計算で転位確率 と開裂確率を計算した。 その結果,

1. 転位反応および開裂反応についてそれぞれの反応 確率を求めることができた。

2. 単環体のコンピューター・シミュレーションで得 られた転位確率と開裂確率を用いて二環体組成の計算を 行った結果，実験的に得られた二環体化合物のそれぞれ の分解回収組成と良い一致を見た。

3.このことから転位反応とランタム開裂を仮定した 数値計算はPPEのような高分子の熱劣化を定量的に解 析する手段として有効であることが明らかとなった.

多くの高分子のコンピューター・シミュレーションの 計算には研究者自らプログラムを組んで, 問題の解決に 当たることは困難であり, 市販の計算ソフトを睡入して 利用することが多い.このようなコンピューター・シ ミュレーションの方法では研究者が直面する問題を有効 に解決できないことが多い. 一方ではコンピューター・ シミュレーションのプログラミングが数学的または物理 学的に専門的で, 高分子の研究内容と相容れないことも ある. しかし，本研究で示した計算モデルとプログラミ ングは基礎的な FORTRANを用いることだけである. それであ高分子の熱分解のような複雑な事象では解析的
な式は複雑であり，かつ正確な解を解析的手法で求める ことは困難である，発達した計算機を用いることにより 複雑な解析式を使用するよりあ容易に熱分解の解析を行 いうることを示した.

さらに,コンピューター・シミュレーションはあとよ り実験結果を再現することが目的ではない. したがって 計算結果が実験結果と合致したということはそれ自体で は有用な結果を得たとはいえない，実験結果との一致は 計算仮定が正しく行われていることの一つの証明と考え るべきであろう，著者らはPPE の熱分解について実験 的に詳しく研究を進めているが，実験的に得られるデー 夕の解析では個別の反応の確率で相対的な速度を求める ことは到底困難であったことから本研究の意義を認める ことができる.

勆 辟 本研究の実施に当たり数値計算の御指導を受けた計 算流体力学研究所, 桑原先生, 橋口さん, 土屋さんに感謝申し あげ，PPE 材料の提供および有用な情報を提供いただいた旭化 成工業(株)ザイロン技術開発部に対してお礼申しおげる.

\section{文献}

1) 高分子論文集, 51, 38 (1991)（計算機特集号).

2) 相川 泰, 高分子論文集, 51, 237 (1994).

3) 松山一夫, 瓜生敏之, 高分子論文集, 49, 249 (1992).

4) J. Bicerano, Ed., "Computational Modeling of Polymers", Marcel Dekker, New York, N.Y. (1990).

5) E. A. Colbourn, "Computer Simulation of Polymers", Polymer Science \& Technology Series, Longman Scientific \& Technical, London (1994).

6) 武田邦彦, コンピューターシミュレーション, 5, 5 (1994).

7) 小田和弘, 堤 浩司, 武田邦彦, マテリアルライフ学会 第 8 回研究発表会, 東京 (1996)

8) T. Usami, Polymer, 33, 3024 (1992).

9) R. Chandra, Prog. Polym. Sci., 8, 469 (1982).

10) 武田邦彦, 大木伸介, 七条謙一, 高山茂樹, マテリアル ライフ学会誌, 7, 126 (1995).

11) A. Factor, J. Org. Chem., 35, 57 (1970).

12) 武田邦彦, 新井 剛、木下雅夫, 高分子論文集, 53, 284 (1996).

13）津田孝夫, “モンテカルロ法とシミュレーション”, 培風 館, 東京 (1986), p. 3.

14) 戸川隼人, “数値計算とシミュレーション”, 共立全書, 共立出版, 東京 (1985), p. 9.

15）森 正武, “数値計算プログラミング”, 岩波書店, 東京 (1990), p. 41.

16) 木下雅夫, 武田邦彦, マテリアルライフ学会第 8 回研究 発表会, 東京 (1996).

17) A. S. Hay, H. S. Blanchard, G. F. Endres, and J. W. Eustance, J. Am. Chem. Soc., 81, 6335 (1959).

18) A. S. Hay, Adv. Polym. Sci., 4, 496 (1967).

19) D. M. White and H. J. Klopfer, J. Polym. Sci., Part A-1. 10, 1565 (1972).

20) J. Jachowicz, J. Appl. Polym. Sci., 22, 2891 (1978). 
A Study on Thermal Degradation Process of Poly(phenylene ether) under the Assumption of Random Cleavage by Computer Simulation

Hiroaki KondoH*1, Masao Kinoshita*1, Toshiaki TsuChIYA*2, and Kunihiko TAKedA*1

*1Shibaura Institute of Technology, Department of Materials Science (3-9-4 Shibaura, Minato-ku, Tokyo, 108 Japan)

${ }^{* 2}$ Shibaura Institute of Technology, Local and Environmental Research Section (3-9-14 Shibaura, Minato-ku, Tokyo, 108 Japan)

The thermal degradation process and scission products of poly(phenylene ether) [poly(oxy-2,6-dimethyl-1,4phenylene)] have been studied by computer simulation. Calculated values were in good agreement with experimental data in the case of dimeric scission products as well as for monomeric products. In particular, the concentrations of dimeric scission products calculated with the parameters of reaction probabilities could account for the experimental values. Several quantitative values of scission rate probabilities could be obtained: rearrangement probability of PPE main chain from the ether bridge to the methylene bridge $(78 \%)$, cleavage ratio of the methylene and ether bridge on main chain, and cleavage ratio of side chain. The reaction processes of PPE thermal degradation could be elucidated more quantitatively than experimental attempts. This study may also contribute to computer simulation of polymer science without using some difficult mathematical equations, and physical treatments such as molecular dynamics.

KEY WORDS Poly(phenylene ether) / Thermal Degradation / Rearrangement Reaction / Random Cleavage / Computer Simulation /

(Received August 1, 1996: Accepted February 7, 1997)

[Kobunshi Ronbunshu, 54(6), 365-374 (1997)] 